\title{
Credibility to attract, trust to stay: the mediating role of trust in improving brand congruence in sports services
}

\section{Mario Alguacil and María Huertas González-Serrano}

Faculty of Teaching and Educational Sciences,

Catholic University of Valencia, Sacre Cor, 5. 46113 Valencia, Spain

Email: mario.alguacil@ucv.es

Email: mh.gonzalez@ucv.es

\section{Ana María Gómez-Tafalla*}

Faculty of Sport Science,

University of Valencia,

Gascó Oliag, 3, 46010 Valencia, Spain

Email: ana.maria.gomez@uv.es

*Corresponding author

\section{Rómulo Jacobo González-García}

Valencian International University,

Pintor Sorolla, 21, 46002 Valencia, Spain

Email: romulojacobo.gonzalez@campusviu.es

\section{Sergio Aguado-Berenguer}

Faculty of Sport Science,

University of Valencia,

Gascó Oliag, 3, 46010 Valencia, Spain

Email: sergio.aguado@uv.es

\begin{abstract}
This research aims to demonstrate the mediating role of brand trust in the relationship between credibility and users' congruence with a sports services brand. The analysis was carried out using EQS 6.3 to perform the four required steps of the analysis (and the Sobel test was conducted for a public sports service and a private sports service. The results confirm the full mediation effect of brand trust in the case of the private service and a partial mediation for the public service. Therefore, this study confirms that credibility, in the presence of trust, ceases to have an influence on the congruence of users with the brand, which suggests that credibility is important at an initial stage to attract the user, but at more advanced stages, trust must be developed to ensure that users are more congruent with the brand and can, therefore, be identified with it and be more loyal.
\end{abstract}


Keywords: brand trust; credibility; congruence; mediating role; mediation analysis; sport services; marketing; sports marketing; management; sports management; branding; brand image.

Reference to this paper should be made as follows: Alguacil, M., GonzálezSerrano, M.H., Gómez-Tafalla, A.M., González-García, R.J. and AguadoBerenguer, S. (2021) 'Credibility to attract, trust to stay: the mediating role of trust in improving brand congruence in sports services', European $J$. International Management, Vol. 15, Nos. 2/3, pp.231-246.

Biographical notes: Mario Alguacil has $\mathrm{PhD}$ in Sport Management. He is Professor at the Faculty of Educational Sciences at the Catholic University of Valencia. He presents research results in national and international journals and conferences about brand perception in sports services, events and sport-related entities, and their relationship with perceived performance and consumer behaviour, as well as studies related to different aspects of sports management and marketing.

María Huertas González-Serrano is Professor at the Faculty of Educational Sciences at the Catholic University of Valencia, specialises in sports management and entrepreneurship. Her $\mathrm{PhD}$ is in physical activity and sport (sport entrepreneurship specialisation). She has participated in several research projects in sports management and has published several articles about sport entrepreneurship and intrapreneurship.

Ana María Gómez-Tafalla is Professor at the Faculty of Sport Sciences (University of Valencia, Spain). She is a specialist researcher in sport management, with a long experience in public management. She participates in several research projects in sport management and presents research results in conferences and journals, focusing on user satisfaction, the economic impact of sport events and the demand for physical activity from citizens.

Rómulo Jacobo González-García is Professor in the International University of València (Spain) from the sports management and tourism field. His $\mathrm{PhD}$ is in physical activity and sport (sport tourism specialisation). He has participated in several research projects in sports management, and has published several articles about the socio-economic impact of the sporting events.

Sergio Aguado-Berenguer is Professor at the Faculty of Sport Sciences in Valencia, Spain. He obtained his $\mathrm{PhD}$ in Sports Management and is a specialist in Sports Events, participating in several organising committees of regional, continental or world championships. He has published several research papers focusing on user satisfaction and the economic impact of sports events.

\section{Introduction}

Sports brands are an important asset for organisations; therefore, sports act as a marketable product in the global business environment (Ratten and Ratten, 2011). The brand image has to do with the meanings that consumers perceive from the brand, from which it is remembered, described and related (Dowling, 1986). This aspect has been analysed from various approaches (Dwivedi and McDonald, 2018), although the majority of studies have been aimed at the analysis of tangible goods, not services (Bougoure 
et al., 2016), with little research on sports services. Currently, the market for sports services is very competitive, so a fundamental step must be to identify the competition to try to obtain a competitive advantage over it (Yu et al., 2015). On many occasions, the services offered to users are very similar, which is why, because brand image affects consumer behaviour (Burmann et al., 2008), the brand can be a differential factor that makes users prefer one service to another; additionally, the unique associations related to the brand affect the functioning of the marketplace (Brexendorf and Keller, 2017).

However, despite its importance, brand perception in the context of sports services is an emerging and almost unexplored topic, so it is important to understand the various relationships that are established between the different variables of interest to obtain information on what these relationships are, if they are influential and, if so, to what extent they are influential. Within these relationships, there are two variables, credibility and trust, which are usually associated logically with the idea that something that is credible generates trust; therefore, it is a very logical relationship. On many occasions, marketing strategies are aimed at generating credibility, understanding that such credibility will make users more congruent with the brand and increase their identification with the brand. Therefore, consumers' probability of being loyal is greater (He and Li, 2010), as they feel that the brand is something that identifies them and in a certain way makes them express what they are. In this sense, trust is usually established as a variable related to credibility and, consequently, authenticity (Portal et al., 2019), and indeed it is, but there has been no analysis of the possible mediating role that trust can play in the relationship between brand credibility and the congruence of users with it.

This research aims to verify whether there is a mediating effect of trust in the relationship between the credibility we perceive of the brand and the congruence we feel with it, analysing a public and a private sports service. The hypothesis put forward in this study is that trust will mediate the relationship between credibility and brand congruence so that in the presence of trust, credibility will lose its protagonism, and this affirmation will be fulfilled in both the private and public services (H1 and H2). The confirmation of these hypotheses does not mean that credibility ceases to be important in the process; simply, these results would suggest that the importance of the role of credibility would be produced at an initial stage, as they are useful to attract potential consumers to test the service, but at a later stage, where the user already makes use of the service and where the trust that the user can develop with it comes into play, we must pay close attention. Therefore, brand trust would get the most users of the service to be congruent with the brand, which would increase the likelihood that users feel greater identification with it and would be more loyal. The analysis of brand perception in sports services and its relationship with variables such as the congruence of users with the brand is a little examined field of research to date. In addition, there are no studies in which the mediating role of trust is analysed, so this research provides novel answers in the study of the relationship between fundamental variables and business success.

\section{Theoretical background}

\subsection{International sports management}

Sports management is an area that has received relatively little research attention but has grown and developed a great deal over time. If we look at the past and analyse its 
evolution, in the 1990s, Chelladurai (1992) addressed the situation of the research area in sports management, indicating that it is a field in which there is no specialisation and, therefore, researchers from other areas do not pay as much attention to it as they should. This author suggests that specialised bodies should be created within the area, knowing that this would cause overlaps with other areas such as economics and administration, but understanding that sports management would not only have much to learn from these areas but also have much to offer them, prioritising practical applicability so that the discipline will make sense. In this evolution, Pitts (2001) establishes that the discipline has advanced substantially in a short time and states that sports management would have many opportunities in the future. Chalip (2006) maintains that sports management is relatively young compared to other disciplines, which has advantages and disadvantages, and that if we really want sports management to be a peculiar or different area from others, we should raise the possibility that sports management contains differential aspects, not just the application of management principles to the sports context. In this sense, traditional and emerging topics in the business world have been adapted to the sporting context to explore the unique features that must be valued. This is why, for instance, aspects such as corporate social responsibility (García-Sánchez and Martínez-Ferrero, 2019; Oh et al., 2019; Valle et al., 2019; Vveinhardt et al., 2019) and entrepreneurship (Ratten, 2018; Baier-Fuentes et al., 2019; Jones et al., 2019; Kalhor et al., 2019), which were strongly oriented to the business world, have also been developed in the sporting context (Bradish and Cronin, 2009; Ratten, 2011; GonzálezSerrano et al., 2018; Ratten and Tajeddini, 2019, Zeimers et al., 2019).

In the diversification noted by the experts, sports management has been expanding its lines of research, currently attending to various aspects, including, for instance, the study of quality and satisfaction in sports services (García-Fernández et al., 2012; Calabuig et al., 2015), the analysis of the impact of events and sports tourism (Parra-Camacho et al., 2012; González-García et al., 2018), as well as other lines of research in which sports management overlaps with marketing, such as the analysis of sponsorship in sports (Alonso Dos-Santos et al., 2018; Alonso Dos-Santos et al., 2019) or the line of the present study, which is the analysis of the brand image of users of sports services (Alguacil et al., 2018; Crespo-Hervás et al., 2018).

In the future, sports management will continue to grow and evolve. We can say that it is a discipline with good adaptability to the environment because it responds to emerging lines of research in recent years, such as the analysis of online consumer behaviour (Alonso Dos-Santos et al., 2017), the role of social media in sports management (LópezCarril et al., 2019) or the analysis of the impact of e-sports (Heere, 2018).

\subsection{Credibility}

Brand credibility is an aspect that has been analysed in many studies, but most of them have focused on the analysis of tangible products, while the analysis of credibility in services has not received as much attention (Bougoure et al., 2016). This topic is even more rarely studied in the field of sports services, where few contributions study the effect of brand perception - in this case, credibility - on other variables of interest. In relation to this concept, Erdem and Swait (1998) analysed credibility as a concept based on signal theory. This theory, as established by Connelly et al. (2011), is very useful for 
understanding behaviours when two parties, which, in this case, could be brand and user, have access to different information. The brand would be in charge of communicating (sending signals), and the user would be in charge of interpreting that signal in one way or another. The objective of the ideal marketing strategy would be for the signal sent to be interpreted as the sender understands it, which would result in a perfect match. Within the context of marketing, this theory is fundamental because the messages will be effective when users interpret them as credible and relevant (Dunham, 2011). Therefore, this type of research, which tries to better understand the functioning of credibility in the context of sports services, may help brands be able to send credible signals that can overcome consumer doubts or scepticism about the brand.

Based on a concrete conceptualisation, credibility is based on the premises that a company fulfils the promises it makes (Herbig and Milewicz, 1995). A brand is considered credible when users consider that the information they receive from it is reliable and when they assess positively the history of that brand in terms of its marketing strategies (Bougoure et al., 2016). According to Erdem and Swait (2004), credibility has to do with the ability to believe in the information from a brand, always from the point of view of consumers, and can also be understood as the ability and commitment to continuously deliver what has been promised. In this sense, the same authors divide the concept into two components: trustworthiness, which is related to the intention of the brand to deliver what it has promised, and expertise, which is related to the ability of the brand to deliver what it has promised, being more influential in generating credibility among users regarding the brand's intention to deliver rather than its ability to do so. In addition, credibility is an element that has a cumulative character (Erdem et al., 2002), where it is not enough to be credible once; however, when users consider a brand to be credible, it is because that brand has been transmitting credibility in the different marketing actions carried out over time.

\subsection{Brand trust}

Brand trust is a concept that logically appears linked to brand credibility because perceiving a brand as credible also improves perceived quality levels as well as a lower sense of risk (Baek and King, 2011); thus, the more perceived credibility is, the less risk and greater trust, which will cause the user to perceive low uncertainty in the commercial relationship with the brand (Frasquet et al., 2017). At a conceptual level, brand trust is related to the sense of security that consumers have when interacting with a brand (Delgado-Ballester et al., 2003), which is why purchasing processes are influenced by trust between the parties (Kim and Walker, 2013). In this sense, brand trust is also related to the feeling that the brand will try to solve problems that might arise (Kim et al., 2018).

According to authors such as Aaker (1997) or Fournier (1998), we can trust brands in the same way that we trust people, so a brand can go beyond customer satisfaction or performance (Belaid and Behi, 2011). These same authors argue that trust can be understood from a cognitive and an affective perspective. From a cognitive perspective, trust is related to credibility, which has to do with the information communicated by the brand, its performance and its ability to satisfy the user's needs. On the other hand, affectivity is related to integrity (Tong et al., 2018), where the brand is considered honourable when it respects its promises and prioritise the long-term interests of 
consumers. Brand trust will transform an orientation based on a customer-brand transaction into a lasting, close and personal relationship with the brand (Tong et al., 2018). Previous research understands that trust must be enhanced through experience with the brand over time and that the user's evaluation will have to do with direct aspects, such as the use of the service or their satisfaction with it, or with indirect aspects, such as brand advertising or service recommendation (Delgado-Ballester and MunueraAlemán, 2001). According to these same authors, this experience will be very relevant in generating trust because it generates associations and feelings that provide more certainty.

\subsection{Congruence}

Congruence is an element that has been analysed in terms of attachment and with reference to loyalty (Karampela et al., 2018). This concept can be understood as the degree of coincidence or fit between the brand image and the user's own image, unlike identification, which can be understood as a step beyond, closely linked to congruence, that has to do with the user feeling part of the organisation and feeling as his/her own the success and failure of the brand. The theory of self-congruence (Johar and Sirgy, 1991) defines the value of congruence as a mental comparison that consumers make with respect to the similarity or dissimilarity of an entity's values and its own values, which may partially influence consumer behaviour (Hamilton and Sun, 2005). The concept of congruence has a theoretical basis, such as the cognitive theory of Festinger (1957). This theory establishes that consumers tend to act as they think, so when they buy a brand with which they do not have that coincidence between their self-image and the image they perceive of the brand, there is a dissonance, which conditions their purchase decision. Although it is true that the influence of that congruence may vary depending on the ownership of the service or cultural aspects (Bajac et al., 2018), consumers will always tend to be more attracted to brands that are more congruent with their own image (Kwak and Kang, 2009).

In this line, in which we comment that users buy brands similar to them, it must also be said that purchase processes are motivated not only by satisfying functional needs but also by acquiring brands that satisfy the needs of social approval, personal expression or self-esteem (Pitta and Katsanis, 1995). Because buying a brand helps consumers express their identity, consumers will identify more with brands that help them express what they are or want to be, and will do so to a greater extent in earlier stages (Belk, 1988) than with other brands. The concepts of congruence and identification have often been referred to as a single dimension, in which no conceptual differentiation is made. Identification, as defined by Kim et al. (2001), has to do with the degree to which the brand expresses and reinforces consumers' identity. As mentioned above, identity goes a step beyond, subsequent to the affinity with the brand, which implies greater involvement with it.

Despite the fact that there is extensive literature on these terms in the field of marketing, the study of these variables in the context of sports services is almost nonexistent, so this research focuses on learning more about the functioning of these relationships in order to provide information to improve the management of sports services. 


\section{Method}

\subsection{Sample}

The population under study included the users of two sports services in the city of Valencia (Spain). The sample obtained consists of a total of 690 users, of which 344 (49.86\%) belong to a private sports service and $346(50.14 \%)$ to a public sports service. In the case of the private service, $84 \%$ of the 344 users are men. Of the total number of users, $45 \%$ are between 31 and 45 years old, $44 \%$ are between 18 and 30 years old and $73 \%$ are full-time workers. On the other hand, for the public service, of the 346 users, $74 \%$ are women. Of the total, the majority are between the ages of 31 and 45 years (57\%), and $44 \%$ are full-time workers. The selection criteria for the sample have been to survey adult users who are part of the service and who attend the facilities regularly.

\subsection{Instrument}

To obtain the necessary information related to the variables of interest, a questionnaire was carried out with three scales that measure the credibility, trust and congruence of the users with the brand using three items for each construct. These scales have been extracted from the existing literature in the field of marketing and were adapted to the context of sports services, obtaining adequate psychometric properties. These properties include Cronbach's alpha values greater than .70 (Hair et al., 2006) incredibility scale $(\alpha=.90)$, congruence scale $(\alpha=.88)$ and brand trust scale $(\alpha=.92)$. In addition, composite reliability values were higher than .70 (Hair et al., 2006), and AVE values were higher than .50 in all cases (Fornell and Larcker, 1981). After the confirmatory factorial analysis, we can conclude that in the three scales, the RMSEA value was lower than .08 (Browne and Cudeck, 1993), the item weights exceeded .60 (Bagozzi and Yi, 1988) and the $\mathrm{T}$ values were above 1.96 (Veasna et al., 2013) in all cases. Finally, it is confirmed that the values of the indexes of goodness of fit have been higher than .90 (Hu and Bentler, 1999) and have, therefore, been adequate for the three variables analysed. The credibility scale has been extracted from Sweeney and Swait (2008), while the brand trust scale has been obtained from the contribution of Hur et al. (2014), and the scale of congruence of users with the brand has been adapted from Grace and O'Cass (2005). The scales are composed of statements on the different topics with a Likert response scale of five points, where 1 means being in total disagreement with the statement and 5 means being in total agreement.

\subsection{Statistical analysis}

First, a descriptive analysis has been carried out for the variables of interest, in this case, credibility, trust and brand congruence, so that the average and standard deviation of the users of both the public and private sports services could be known. Subsequently, to test the hypothesis, a mediation analysis was carried out with the EQS 6.3 software. To this end, the four necessary steps established in the literature have been followed (Baron and Kenny, 1986), and the Sobel test (1982) has been carried out for both the public and private sports services. 


\section{Results}

\subsection{Descriptive analysis of the variables}

As for the descriptive results of the variables of interest, as shown in Table 1, the best values for both private and public service users appear for the credibility variable, with values of $3.76( \pm .74)$ and $3.56( \pm .92)$, respectively. On the other hand, in the worst valued items, there is again a coincidence, with the worst values appearing for the congruence variable and showing a value of $3.41( \pm .83)$ for the private service case and $3.34( \pm .94)$ for the public one. The descriptive results also show that, for all variables, the average user ratings are more positive in the case of the private sports service. These mean differences have been confirmed as significant for the variables of credibility $(p<.01)$ and trust $(p<.01)$ but not for congruence $(p>.05)$.

Table 1 Descriptive results of the variables according to the ownership of the service

\begin{tabular}{lcccc}
\hline Variable & Ownership & Mean & SD & P value \\
\hline \multirow{2}{*}{ Credibility } & Private & 3.76 & .74 & $* *$ \\
& Public & 3.56 & .92 & $* *$ \\
\multirow{2}{*}{ Trust } & Private & 3.73 & .77 & \\
& Public & 3.54 & .98 & \\
\multirow{2}{*}{ Congruence } & Private & 3.41 & .83 & .94 \\
\hline
\end{tabular}

Notes: $\quad * p<.05 ; * * p<.01$.

\subsection{Mediation model}

As for the mediation analysis, the proposed model (see Figure 1) aims to test whether trust has a mediating effect to explain users' congruence with the brand, starting from the credibility they perceive for the private service and the public one.

Figure 1 Mediation model of brand trust

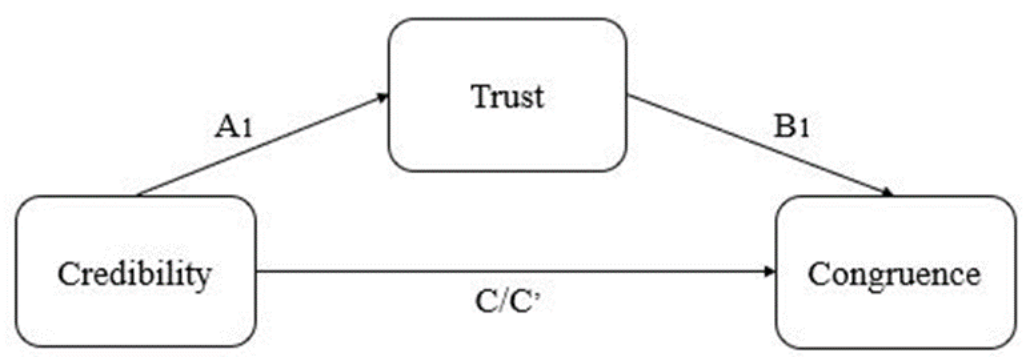

Once the analysis has been carried out, it can be confirmed that both models show a suitable fit, complying with the goodness-of-fit indices for both the private $(\mathrm{S}-\mathrm{B} \chi 2=46.16 ; \chi 2=59.19 ; \mathrm{gl}=24 ; \chi 2 / \mathrm{gl}=2.47 ; \mathrm{RMSEA}=.05(\mathrm{IC}=.029-.075)$; $\mathrm{NFI}=.96 ; \mathrm{NNFI}=.97 ; \mathrm{CFI}=.98 ; \mathrm{IFI}=.98)$ and public models $(\mathrm{S}-\mathrm{B} \chi 2=38.09$; 
$\chi 2=51.01 ; \mathrm{gl}=24 ; \chi 2 / \mathrm{gl}=2.13 ; \mathrm{RMSEA}=.04(\mathrm{IC}=.012-.066) ; \mathrm{NFI}=.98 ; \mathrm{NNFI}=$ .99 ; CFI = .99; IFI = .99). Both models explain $66 \%\left(\mathrm{R}^{2}=.66\right)$ of users' congruence, with the weight of trust being greater than the weight of credibility in both the private service (Trust: $\beta=.78 ; p<.05$; Credibility: $\beta=.04 ; p>.05$ ) and the public service (Trust: $\beta=.69 ; p<.05$; Credibility: $\beta=.15 ; p<.05$ ).

Once the proper fit of the private and public sports service models was known, the four steps established by Baron and Kenny (1986) were followed to verify the mediating role of trust, followed by the subsequent application of the Sobel test (1982). Table 2 shows the beta coefficients and $\mathrm{T}$ values obtained in each of the steps for both the private and public models.

Table 2 Beta coefficients and T-values of mediation analysis

\begin{tabular}{llc}
\hline \multirow{2}{*}{ Hypothesis } & \multicolumn{2}{c}{ Mediation test } \\
\cline { 2 - 3 } Private & Beta & T-value \\
\hline H1: Step 1. ID - DP Credibility - Congruence & .76 & $10.69^{*}$ \\
H2: Step 2. ID - MD. Credibility - Trust & .84 & $13.05^{*}$ \\
H3: Steps 3 \& 4. ID \& MD - DP & & .48 \\
$\quad$ Credibility - Congruence & .05 & $8.13^{*}$ \\
$\quad$ Trust - Congruence & .88 & $12.63^{*}$ \\
\hline Public & & $15.74^{*}$ \\
\hline H1: Step 1. ID - DP. Credibility - Congruence & .72 & \\
H2: Step 2. ID - MD. Credibility - Trust & .82 & $2.15^{*}$ \\
H3: Steps 3 \& 4. ID \& MD - DP & & $9.72^{*}$ \\
$\quad$ Credibility - Congruence & .16 & .71 \\
Trust - Congruence
\end{tabular}

Notes: $\quad * p<.05$.

ID: independent variable; DP: dependent variable; MD: mediating variable.

To determine whether there is complete mediation, we introduce the mediating variable (trust) into the model, and the significant relationship that exists between the independent variable (credibility) and the dependent variable (congruence) must cease its significant influence, while trust must predict the dependent variable significantly. Based on the results of the mediation analysis, we can observe, as in the case of the private sports service, that the relationship established in step 1 between credibility and congruence $\left(\mathrm{B}=.76 ; \mathrm{T}=10.69^{*}\right)$ ceases to be significant with the introduction of trust in steps 3 and 4 ; in this case, the relationship between credibility and congruence has a value of $\mathrm{B}=.05$ and a value of $\mathrm{T}=.48$, which is no longer significant, while the relationship between trust and congruence has a value of $\mathrm{B}=.88$ and a value of $\mathrm{T}=8.13^{*}$, which indicates that the relationship is significant.

On the other hand, in the mediation analysis of the public service, we can see how the significant relationship between credibility and congruence, which previously showed 
values of $\mathrm{B}=.72$ and $\mathrm{T}=12.63^{*}$, greatly decreases its influence with the introduction of the trust variable because the relationship between credibility and congruence shows a value of $\mathrm{B}=.16$ and a value of $\mathrm{T}=2.15^{*}$, while the proposed relationship between trust and congruence shows a value of $\mathrm{B}=.71$ and a value of $\mathrm{T}=9.72 *$. In this second case, for the public sports service, we see how the relationship between credibility and congruence does not cease to be significant with the introduction of trust, although its influence is greatly reduced.

Once the values of relationships and the changes that occur with the introduction of brand trust within the mediation model are known, it is necessary to carry out the Sobel test (1982). The application of this test allows us to confirm that there is a complete mediating effect of brand trust in the relationship between perceived credibility and user congruence in the case of the private service $(\mathrm{Z}=6.89 ; p<.001)$ because, in addition to the significance of this Sobel test, the relationship between credibility and congruence, which was significant prior to the introduction of trust, ceases to be so when trust comes into play. On the other hand, the Sobel test (1982) also confirms - although in this case, partially - the mediating role of trust in the public service $(\mathrm{Z}=8.23 ; p<.001)$ because the values obtained are significant; however, in this case, the relationship between credibility and congruence is significant with the introduction of trust, so we must discuss partial mediation.

\section{Discussion}

Brands within the sports industry have been an interesting aspect to study; in fact, it has been shown that many athletes build their own brands by participating in different marketing campaigns (Ratten, 2015), and many sports teams generate millions of dollars with ticket sales and official merchandising, most of which comes from their brands (Ratten and Ratten, 2011). However, despite the importance of the brand in the sports industry, there are still few studies that analyse the brand in sports services, so it is necessary to investigate the variables that influence congruence and therefore the identification of users. In relation to the variables that form part of the analyses that have been carried out, they have been very much addressed in the marketing environment, although as we said, the sporting context is little analysed; additionally, it would be interesting to know whether the relationships that are usually established in other areas can also be confirmed in the world of sports services and to identify certain relational aspects between the variables that can provide valuable information for marketing strategies in areas other than sports.

The relationship between credibility and trust is a close one. The concept of credibility is evaluated holistically both in the pre-purchase phase and in the purchase and post-purchase phases. Furthermore, in the current digital world, it is important to improve the user experience to improve credibility because the experience can lead to site recommendations, and those recommendations can add to the credibility pursued (Dwivedi et al., 2018). On the other hand, credibility has been related to other variables, such as purchase intentions, in such a way that the fact of perceiving credibility means that a higher quality is perceived and the sensation of risk is lower (Baek and King, 2011). This phenomenon is related to trust because if credibility lowers the perceived risk, trust becomes easier to acquire. The variable of trust improves aspects such as perceived quality, value and satisfaction with the service (Calabuig et al., 2010), which 
improves the subjective well-being of users in sports services (García-Pascual et al., 2016) as well as future intentions (Zboja and Voorhees, 2006). Trust has also proven to be influential on loyalty (Chaudhuri and Holbrook, 2001) and its mediating role between quality and satisfaction (Gummerus et al., 2004) as well as between satisfaction and loyalty (Choi and La, 2013). However, no literature has analysed the mediating role of trust between credibility and the congruence of users with the brand, which would allow identification with the brand and, consequently, with the sports service.

In terms of congruence, the higher the user's congruence with the brand, the higher the purchase intentions (Sirgy and Johar, 1999) as well as loyalty and satisfaction, so brands must customise their image to connect with the own image of their target audience (Chebat et al., 2006). In this line, congruence has proved to be influential on loyalty (Kressmann et al., 2006) as well as on the attitudes generated towards the brand (Ghantous, 2016) and variables, such as satisfaction, trust, commitment, loyalty and recommendation (Zhang and Bloemer, 2008). Finally, the value of congruence influences identification (Bhattacharya and Sen, 2003; Hamilton and Sun, 2005). User identification is an aspect that positively influences commitment (Brown et al., 2005) because, as Bhattacharya and Sen (2003) stated, user identification causes a psychological link to be generated with the organisation, which motivates them to be committed to achieving their objectives. This identification also has an influence on loyalty ( $\mathrm{He}$ and $\mathrm{Li}, 2010$ ), so attempting to achieve the congruence of the user with the brand and, consequently, the user's identification with it must be a prerequisite step to develop user loyalty, so the brand can benefit from having more loyal users.

\section{Conclusions}

In the private sports service, trust has a fully mediating effect on the relationship between perceived credibility and users' congruence with the brand. On the other hand, in the public service, although the introduction of trust in the model greatly diminishes the influence of credibility, the latter does not cease to be significant in the prediction, so in this case, we can say only that partial mediation exists. This research proves the total and partial mediating effect of brand trust when explaining the congruence with users' perceptions of the brands of the private and public sports services.

\section{Managerial implications}

The knowledge of brand perception and the relationships established between its variables is interesting for managers and marketing managers, in this case, in the field of sports. First, knowing the opinion regarding these variables allows the entity to know where it is, the strengths they must maintain and the weaknesses they must solve, allowing us to check whether the strategies they had planned are fulfilling their objectives. In addition, as demonstrated in this research, some variables have a mediating role in relationships that are commonly examined in the field of branding, which allows new information to be provided so that marketing strategies can be modified. These modifications will make the strategies more effective, requiring less resources and better reaching users, which will also make users receive better communication. 
More specifically, as explained throughout the paper, congruence is beneficial for the identification of users with the brand and, consequently, their loyalty to it. Therefore, when managers carry out the marketing strategies they have planned, they should not focus on credibility only because it ceases to be partially or totally important when trust comes into play. Therefore, instead, when the objective is no longer to attract consumers but for consumers to perceive that the brand is similar to them, which can make them identify with the brand, the strategies must be oriented towards generating high levels of trust.

\section{Limitations and future lines of research}

In terms of limitations and future lines of research, the main limitation of the study is the choice of a public service and a private service without distinguishing the category of service. That is, within the private sector, we can find, for instance, low-cost, premium and boutique services, which have different peculiarities and which are logically aimed at different audiences, so it would be interesting to analyse whether the conclusions drawn in this research are also produced in each market segmentation. It would also be interesting, within the public sphere, to differentiate between centres with direct and indirect management to see whether differences are found and to have a broader perspective on the scope of services.

\section{References}

Aaker, J. (1997) 'Dimensions of brand personality', Journal of Marketing Research, Vol. 24, No. 3, pp.347-356.

Alguacil, M., Nunez-Pomar, J.M., Valantine, I., Crespo-Hervás, J., Perez-Campos, C. and Staskeviciute-Butiene, I. (2018) 'The importance of the services brand in predicting loyalty and word of mouth', Engineering Economics, Vol. 29, No. 4, pp.446-454.

Alonso Dos-Santos, M., Rejón Guardia, F. and Calabuig, F. (2018) 'Sponsorship image transfer theory in virtual brand communities', Industrial Management \& Data Systems, Vol. 118, No. 6, pp.1287-1302.

Alonso-Dos-Santos, M.A., Calabuig-Moreno, F. and Franco, M.S. (2019) 'Congruence and placement in sponsorship: an eye-tracking application', Physiology \& Behavior, Vol. 200, pp.159-165.

Alonso-Dos-Santos, M.A., Calabuig-Moreno, F., Montoro-Ríos, F. and Alguacil, M. (2017) 'Online sport event consumers: attitude, E-quality and E-satisfaction', Journal of Theoretical and Applied Electronic Commerce Research, Vol. 12, No. 2, pp.54-70.

Baek, T.H. and King, K.W. (2011) 'Exploring the consequences of brand credibility in services', Journal of Services Marketing, Vol. 25, No. 4, pp.260-272.

Bagozzi, R.P. and Yi, Y. (1988) 'On the evaluation of structural equation models', Journal of the Academy of Marketing Science, Vol. 16, No. 1, pp.74-94.

Baier-Fuentes, H., Hormiga, E., Miravitlles, P. and Blanco-Mesa, F. (2019) 'International entrepreneurship: a critical review of the research field', European Journal of International Management, Vol. 13, No. 3, pp.381-412.

Bajac, H., Palacios, M. and Minton, E.A. (2018) 'Consumer-brand congruence and conspicuousness: an international comparison', International Marketing Review, Vol. 35, No. 3, pp.498-517. 
Baron, R.M. and Kenny, D.A. (1986) 'The moderator-mediator variable distinction in social psychological research: conceptual, strategic and statistical considerations', Journal of Personality and Social Psychology, Vol. 51, No. 6, pp.1173-1182. DOI:http://dx.doi.org/ 10.1037/0022-3514.51.6.1173

Belaid, S. and Behi, A.T. (2011) 'The role of attachment in building consumer-brand relationships: an empirical investigation in the utilitarian consumption context', Journal of Product \& Brand Management, Vol. 20, No. 14, pp.37-47.

Belk, R. (1988) 'Possessions and the extended self', Journal of Consumer Research, Vol. 15, No. 2, pp.139-168.

Bhattacharya, C.B. and Sen, S. (2003) 'Consumer-company identification: a framework for understanding consumers' relationships with companies', Journal of marketing, Vol. 67, No. 2, pp.76-88.

Bougoure, U.S., Russell-Bennett, R., Fazal-E-Hasan, S. and Mortimer, G. (2016) 'The impact of service failure on brand credibility', Journal of Retailing and Consumer Services, Vol. 31, pp.62-71.

Bradish, C. and Cronin, J.J. (2009) 'Corporate social responsibility in sport', Journal of Sport Management, Vol. 23, No. 6, pp.691-697.

Brexendorf, T.O. and Keller, K.L. (2017) 'Leveraging the corporate brand: the importance of corporate brand innovativeness and brand architecture', European Journal of Marketing, Vol. 51, No. 9/10, pp.1530-1551.

Brown, T.J., Barry, T.E., Dacin, P.A. and Gunst, R.F. (2005) 'Spreading the word: investigating antecedents of consumers' positive word-of-mouth intentions and behaviors in a retailing context', Journal of the Academy of Marketing Science, Vol. 33, No. 2, pp.123-138.

Browne, M.W. and Cudeck, R. (1993) 'Alternative ways of assessing model fit', in Bollen, K.A. and Long, J.S. (Eds): Testing Structural Equation Model, Sage, Newbury Park, pp.136-162.

Burmann, C., Schaefer, K. and Maloney, P. (2008) 'Industry image: its impact on the brand image of potential employees', Journal of Brand Management, Vol. 15, No. 3, pp.157-176.

Calabuig, F., Burillo, P., Crespo, J., Mundina, J.J. and Gallardo, L. (2010) 'Satisfaction, quality and perceived value in athletics spectators', International Journal of Medicine and Science of Physical Activity and Sport, Vol. 10, No. 40, pp.577-593.

Calabuig, F., Prado-Gascó, V., Crespo-Hervás, J., Núñez-Pomar, J. and Añó, V. (2015) 'Spectator emotions: effects on quality, satisfaction, value, and future intentions', Journal of Business Research, Vol. 68, No. 7, pp.1445-1449.

Chalip, L. (2006) 'Toward a distinctive sport management discipline', Journal of Sport Management, Vol. 20, No. 1, pp.1-21.

Chaudhuri, A. and Holbrook, M.B. (2001) 'The chain of effects from brand trust and brand affect to brand performance: the role of brand loyalty', Journal of Marketing, Vol. 65, No. 2, pp.81-93.

Chebat, J.C., Sirgy, M.J. and St-James, V. (2006) 'Upscale image transfer from malls to stores: a self-image congruence explanation', Journal of Business Research, Vol. 59, No. 12, pp.1288-1296.

Chelladurai, P. (1992) 'A classification of sport and physical activity services: implications for sport management', Journal of Sport Management, Vol. 6, No. 1, pp.38-51.

Choi, B. and La, S. (2013) 'The impact of corporate social responsibility (CSR) and customer trust on the restoration of loyalty after service failure and recovery', The Journal of Services Marketing, Vol. 27, pp.223-233. DOI:10.1108/08876041311330717

Connelly, B.L., Certo, S.T., Ireland, R.D. and Reutzel, C.R. (2011) 'Signaling theory: a review and assessment', Journal of Management, Vol. 37, No. 1, pp.39-67.

Crespo-Hervás, J., Alguacil, M. and Núñez-Pomar, J. (2018) 'Gender comparison of the perception of brand image and purchasing preferences of users of a sports service', Journal of Physical Education and Sport, Vol. 18, pp.1276-1284. 
Delgado-Ballester, E. and Munuera-Alemán, J.L. (2001) 'Brand trust in the context of consumer loyalty’, European Journal of Marketing, Vol. 35, No. 11/12, pp.1238-1258.

Delgado-Ballester, E., Munuera-Alemán, J.L. and Yagüe-Guillen, M.J. (2003) 'Development and validation of a brand trust scale', International Journal of Market Research, Vol. 45, No. 1, pp.35-53.

Dowling, G. (1986) 'Managing your corporate images', Industrial Marketing Management, Vol. 15, No. 2, pp.109-115.

Dunham, B. (2011) 'The role for signaling theory and receiver psychology in marketing', in Saad, G. (Ed.): Evolutionary Psychology in the Business Sciences, Springer, Berlin, pp.225-256.

Dwivedi, A. and McDonald, R. (2018) 'Building brand authenticity in fast-moving consumer goods via consumer perceptions of brand marketing communications', European Journal of Marketing, Vol. 52, No. 7/8, pp.1387-1411. DOI:10.1108/ejm-11-2016-0665

Dwivedi, A., Nayeem, T. and Murshed, F. (2018) 'Brand experience and consumers' willingnessto-pay (WTP) a price premium: mediating role of brand credibility and perceived uniqueness', Journal of Retailing and Consumer Services, Vol. 44, pp.100-107.

Erdem, T. and Swait, J. (1998) 'Brand equity as a signaling phenomenon', Journal of Consumer Psychology, Vol. 7, No. 2, pp.131-157.

Erdem, T. and Swait, J. (2004) 'Brand credibility, brand consideration, and choice', Journal of Consumer Research, Vol. 31, No. 1, pp.191-198. Available online at: http://dx.doi.org/ $10.1086 / 383434$

Erdem, T., Swait, J. and Louviere, J. (2002) 'The impact of brand credibility on consumer price sensitivity', International Journal of Research in Marketing, Vol. 19, No. 1, pp.1-19.

Festinger, L. (1957) A Theory of Cognitive Dissonance, Stanford University Press, Stanford.

Fornell, C. and Larcker, D. (1981) 'Evaluating structural equation models with unobservable variables and measurement error', Journal of Marketing Research, Vol. 18, No. 1, pp.39-50.

Fournier, S. (1998) 'Consumer and their brands: developing relationship theory in consumer research', Journal of Consumer Research, Vol. 24, No. 4, pp.343-373.

Frasquet, M., Molla-Descals, A. and Ruiz-Molina, M.E. (2017) 'Understanding loyalty in multichannel retailing: the role of brand trust and brand attachment', International Journal of Retail \& Distribution Management, Vol. 45, No. 6, pp.608-625.

García-Fernández, J., Cepeda-Carrión, G. and Ruíz, D.M. (2012) 'Customer satisfaction and its relationship with the perception of quality in fitness centre: use of the CALIDFIT scale', Journal of Sport Psychology, Vol. 21, No. 2, pp.309-319.

García-Pascual, F.G., Merchán, A.S., Gómez, J.M. and Fajardo, P.E. (2016) 'El efecto de variables de gestión en el bienestar subjetivo de usuarios de centros deportivos', Journal of Sports Economics \& Management, Vol. 6, No. 2, pp.99-111.

García-Sánchez, I.M. and Martínez-Ferrero, J. (2019) 'The relevance of assurance statements on CSR information to independent directors', European Journal of International Management, Vol. 13, No. 1, pp.1-24.

Ghantous, N. (2016) 'The impact of services brand personality on consumer-brand relationship quality', Services Marketing Quarterly, Vol. 37, No. 3, pp.185-199.

González-García, R.J., Añó-Sanz, V., Parra-Camacho, D. and Calabuig, F. (2018) 'Perception of residents about the impact of sports tourism on the community: analysis and scale-validation', Journal of Physical Education and Sport, Vol. 18, No. 1, pp.149-156.

González-Serrano, M.H., Valantine, I., Hervás, J.C., Pérez-Campos, C. and Calabuig, F. (2018) 'Sports university education and entrepreneurial intentions: a comparison between Spain and Lithuania', Education+ Training, Vol. 60, No. 5, pp.389-405.

Grace, D. and O'Cass, A. (2005) 'Service branding: consumer verdicts on service brands', Journal of Retailing and Consumer Services, Vol. 12, No. 2, pp.125-139. 
Gummerus, J., Liljander, V., Pura, M. and Van Riel, A. (2004) 'Customer loyalty to content-based web sites: the case of an online health-care service', Journal of Services Marketing, Vol. 18, No. 3, pp.175-186.

Hair, J.F., Black, W.C., Babin, B., Anderson, R.E. and Tatham, R.L. (2006) Multivariate Data Analysis, 6th ed., Prentice Hall, New Jersey.

Hamilton, M. and Sun, X.H. (2005) 'Actual self and ideal brand image: an application of selfcongruity to brand image positioning', International Communication Association Annual Meeting, 26-30 May 2005, EEUU, New York.

He, H. and Li, Y. (2010) 'Key service drivers for high-tech service brand equity: the mediating role of overall service quality and perceived value', Journal of Marketing Management, Vol. 27, No. 1/2, pp.77-99.

Heere, B. (2018) 'Embracing the sportification of society: defining e-sports through a polymorphic view on sport', Sport Management Review, Vol. 21, No. 1, pp.21-24.

Herbig, P. and Milewicz, J. (1995) 'The relationship of reputation and credibility to brand success', Journal of Consumer Marketing, Vol. 12, No. 4, pp.5-10.

Hu, L.T. and Bentler, P.M. (1999) 'Cutoff criteria for fit indexes in covariance structure analysis: conventional criteria versus new alternatives', Structural Equation Modeling: A Multidisciplinary Journal, Vol. 6, No. 1, pp.1-55.

Hur, W.M., Kim, M. and Kim, H. (2014) 'The role of brand trust in male customers' relationship to luxury brands', Psychological Reports, Vol. 114, No. 2, pp.609-624.

Johar, J.S. and Sirgy, M.J. (1991) 'Value-expressive versus utilitarian advertising appeals: when and why to use which appeal', Journal of Advertising, Vol. 20, No. 3, pp.23-33.

Jones, P., Ratten, V., Klapper, R. and Fayolle, A. (2019) 'Entrepreneurial identity and context: current trends and an agenda for future research', The International Journal of Entrepreneurship and Innovation, Vol. 20, No. 1, pp.3-7.

Kalhor, E., Ashourizadeh, S. and Schøtt, T. (2019) 'An experiment of institutional change in the ecosystem of entrepreneurship: easing sanctions against Iran', European Journal of International Management, Vol. 13, No. 4, pp.435-453.

Karampela, M., Tregear, A., Ansell, J. and Dunnett, S. (2018) 'When opposites attract? Exploring the existence of complementarity in self-brand congruence processes', Psychology \& Marketing, Vol. 35, No. 8, pp.573-585.

Kim, C.K., Han, D. and Park, S.B. (2001) 'The effect of brand personality and brand identification on brand loyalty: applying the theory of social identification', Japanese Psychological Research, Vol. 43, No. 4, pp.195-206.

Kim, M. and Walker, M. (2013) 'The influence of professional athlete philanthropy on donation intentions', European Sport Management Quarterly, Vol. 13, No. 5, pp.579-601.

Kim, M.S., Shin, D.J. and Koo, D.W. (2018) 'The influence of perceived service fairness on brand trust, brand experience and brand citizenship behaviour', International Journal of Contemporary Hospitality Management, Vol. 30, No. 7, pp.2603-2621.

Kressmann, F., Sirgy, M.J., Herrmann, A., Huber, F., Huber, S. and Lee, D.J. (2006) 'Direct and indirect effects of self-image congruence on brand loyalty', Journal of Business Research, Vol. 59, No. 9, pp.955-964.

Kwak, D.H. and Kang, J.H. (2009) 'Symbolic purchase in sport: the roles of self-image congruence and perceived quality', Management Decision, Vol. 47, No. 1, pp.85-99.

López-Carril, S., Villamón, M. and Sanz, V.A. (2019) 'Conceptualisation of social media: opportunities for sport management', Retos, Vol. 1, No. 36, pp.468-473.

Oh, W.Y., Choi, K.J., Chang, Y.K. and Jeon, M.K. (2019) 'MNEs' corporate social responsibility: an optimal investment decision model', European Journal of International Management, Vol. 13, No. 3, pp.307-327.

Parra-Camacho, D., Añó, V., Ayora, D. and Núñez-Pomar, J.M. (2012) 'Social perception of a sporting event impact', Journal of Sports Economics \& Management, Vol. 2, No. 1, pp.34-51. 
Pitta, D.A. and Katsanis, L. (1995) 'Understanding brand equity for successful brand extension', Journal of Consumer Marketing, Vol. 12, No. 4, pp.51-64.

Pitts, B.G. (2001) 'Sport management at the millennium: a defining moment', Journal of Sport Management, Vol. 15, pp.1-9.

Portal, S., Abratt, R. and Bendixen, M. (2019) 'The role of brand authenticity in developing brand trust', Journal of Strategic Marketing, Vol. 27, No. 8, pp.714-729.

Ratten, V. (2011) 'Practical implications and future research directions for international sports management', Thunderbird International Business Review, Vol. 53, No. 6, pp.763-770. DOI:10.1002/tie.20451

Ratten, V. (2015) 'Athletes as entrepreneurs: the role of social capital and leadership ability', International Journal of Entrepreneurship and Small Business, Vol. 25, No. 4, pp.442-455.

Ratten, V. (2018) 'Entrepreneurial intentions of surf tourists', Tourism Review, Vol. 73, No. 2, pp.262-276.

Ratten, V. and Ratten, H. (2011) 'International sport marketing: practical and future research implications', Journal of Business \& Industrial Marketing, Vol. 26, No. 8, pp.614-620.

Ratten, V. and Tajeddini, K. (2019) 'Entrepreneurship and sport business research: synthesis and lessons: introduction to the special journal issue', International Journal of Sport Management and Marketing, Vol. 19, No. 1/2, pp.1-7.

Sirgy, M.J. and Johar, J.S. (1999) Toward an Integrated Model of Self-Congruity and Functional Congruity, ACR European Advances.

Sobel, M.E. (1982) 'Asymptotic confidence intervals for indirect effects in structural equation models', Sociological Methodology, Vol. 13, pp.290-312.

Sweeney, J. and Swait, J. (2008) 'The effects of brand credibility on customer loyalty', Journal of Retailing and Consumer Services, Vol. 15, No. 3, pp.179-193.

Tong, X., Su, J. and Xu, Y. (2018) 'Brand personality and its impact on brand trust and brand commitment: an empirical study of luxury fashion brands', International Journal of Fashion Design, Technology and Education, Vol. 11, No. 2, pp.196-209. DOI:10.1080/ 17543266.2017.1378732

Valle, I.D.D., Esteban, J.M.D. and Pérez, Ó.L.D.F. (2019) 'Corporate social responsibility and sustainability committee inside the board', European Journal of International Management, Vol. 13, No. 2, pp.159-176.

Veasna, S., Wu, W. and Huang, C. (2013) 'The impact of destination source credibility: the mediating effect of destination image', Tourism Management, Vol. 36, pp.511-526. DOI:10.1016/j.tour-man.2012.09.007

Vveinhardt, J., Stonkute, E. and Sroka, W. (2019) 'Discourse on corporate social responsibility in the external communication of agricultural enterprises', European Journal of International Management, Vol. 13, No. 6, pp.864-879.

Yu, C.L., Wang, F. and Brouthers, K.D. (2015) 'Domestic and foreign competitor identification and firm performance', European Journal of International Management, Vol. 9, No. 4, pp. $463-483$.

Zboja, J.J. and Voorhees, C.M. (2006) 'The impact of brand trust and satisfaction on retailer repurchase intentions', Journal of Services Marketing, Vol. 20, No. 6, pp.381-390.

Zeimers, G., Anagnostopoulos, C., Zintz, T. and Willem, A. (2019) 'Organisational learning for corporate social responsibility in sport organisations', European Sport Management Quarterly, Vol. 19, No. 1, pp.80-101.

Zhang, J. and Bloemer, J.M. (2008) 'The impact of value congruence on consumer-service brand relationships', Journal of Service Research, Vol. 11, No. 2, pp.161-178. 